\title{
Computation of Watershed Parameters of Kansa Watershed in Satara Using Remote Sensing and GIS
}

\author{
A. P. Bowlekar \\ Dr. Budhajirao Mulik College of Agricultural Engineering and Technology, Mandki-Palvan, \\ Chiplun-415 641, Ratnagiri, Maharashtra, India
}

\begin{abstract}
In present study Kansa watershed in Satara district of Maharashtra was characterized for watershed parameters. Geographical Information Systems (GIS) and a high-resolution Digital Elevation Model (DEM) has been utilized for the estimation of morphological parameters. Several morphometric parameters have been computed and analyzed viz. linear aspects such as stream order, stream number, stream length, mean stream length, stream length ratio; areal aspects such as drainage density, stream frequency, drainage texture, elongation ratio, circularity ratio, form factor, constant of channel maintenance; relief aspects such as relief, relief ratio, relative relief, ruggedness number, length of overland flow. Impacts of morphometric parameters on flash flood characteristics have also been investigated. The presence of the maximum number of the first order segments shows that the basin is subjected to erosion and also that some areas of the basin are characterized by variations in lithology and topography. The form factor is 0.21 , and the circulatory ratio is 0.42 , which suggests an elongated type of catchment. Elongation ratio is 0.52 , which indicates that watershed has high relief and steep slope. The estimated catchment characteristics may be useful to stimulate hydrological responses of the catchment.
\end{abstract}

Key words: Digital Elevation Model, GIS, Remote Sensing, Kansa watershed, morphometry,

\section{Introduction}

The demand for water has increased manifold due to population growth, irrigation, and industrialization. Therefore, watershed management is necessary and is an important part of sustainable development (Barber 2005). Watershed management requires physiographic landform information such as watershed slope, the configuration of the channel network, location of drainage divide, channel length and geomorphological parameters viz. relative relief, shape factor, circularity ratio, bifurcation ratio, drainage

*Corresponding author: (Email: adwaitbowlekar1808@gmail.com) density for watershed prioritization and implementation of the soil and water conservation measures (Soni et al. 2013).

Morphometric analysis of any watershed provides an account about the topography of the area, geological condition and runoff potential. The morphometric characteristics of a watershed represent its attributes and can help to synthesize its hydrological behavior (Pandey et al. 2004). Traditionally these parameters are obtained from the topographic maps or field surveys. However field mapping is acknowledged as the most accurate way to determine the channel networks, it is often impractical, especially for the large 
area and remote watershed situated in the high altitude mountainous region.

Linear, relief and aerial morphometric parameters are evaluated for development planning of watershed. Linear parameter analyzed includes stream order $(\mathrm{u})$, stream length $(\mathrm{Lu})$, mean stream length $(\mathrm{Lu})$ and bifurcation ratio $(\mathrm{Rb})$. Relief parameter analyzed includes Basin relief(H) and Ruggedness number (HD). Relief aspect of watersheds plays an important role for computing surface and sub-surface water flow, permeability, landform development, Drainage density (Dd), stream frequency (Fs), Form factor (Rf), circulatory ratio (Rc) and Constant Channel Maintenance (C) which helps in drainage development. Drainage density is one of the important indicators of the landform element. It provides a numerical measurement of landscape dissection and run-off potential. The drainage pattern differs a lot in linear, relief and areal morphometric parameters due to difference in geological structure, land form configuration, slope, vegetation and rainfall distribution (Kuldeep and Upasana 2011).

Geographic Information System is powerful tool for computerized mapping and spatial analysis (Soni et al. 2013). Debashis et al. (2002) and Bante et al. (2012) carried out morphometric analysis of watershed using remote sensing and GIS. Nageswara et al. (2010) analyzed morphometry of Gostani river basin in Andhra Pradesh using Spatial Information Technology, GIS, and image processing techniques. The basin morphometric parameters such as linear and aerial aspects of the river basin were determined and computed. It was observed that the drainage density $\left(1.18 \mathrm{~km} / \mathrm{km}^{2}\right)$ was low indicating that the basin has highly permeable sub-soil and thick vegetative cover. The circularity ratio $(0.42)$ value revealed that the basin is strongly elongated and highly permeable homogenous geologic materials.

Sharma (2014) carried out morphometric analysis of Imphal river basin using GIS. Drainage density $\left(2.84 \mathrm{~km} / \mathrm{km}^{2}\right)$, circulatory ratio $(0.35)$ and elongation ratio $(0.53)$ showed that the area has a gentle slope, low rainfall, permeable bedrock, fine drainage texture, and narrow and elongated basin. The low value of relief ratio (0.04) of the basin characterizes less resistant rocks indicating erosional processes in the area. In present study, an attempt has been made to study watershed characteristics of Kansa watershed using Remote Sensing and Geographic Information System.

\section{Materials and Methods Studyarea}

Kansa watershed $\left(17^{\circ} 24^{\prime}\right.$ to $17^{\circ} 50^{\prime} \mathrm{N} ; 7^{\circ} 46^{\prime}$ to $74^{\circ} 00^{\prime}$ E) lies in Satara district of Maharashtra state and covers area of 6250 ha at an elevation of $582 \mathrm{~m}$ above MSL. The area falls under sub-montane zone and majority of area is grouped under II, III, IV, VI and VII land capability classes. The length of Kansa river is $21.29 \mathrm{~km}$.

Average daily temperature in this zone is $27^{\circ} \mathrm{C}$ and May is the hottest month. Average annual rainfall is about $1300 \mathrm{~mm}$. The soil derieved from laterite have dark reddish to yellowish red colour with texture varying from clay to clay loam. Soil moisture varies from 6 to 8 $\%$ and $\mathrm{pH}$ from 4 to 5.8 . The cropping pattern of the watershed is dominated by cereals with rice and millets as major kharif seaon crops.

\section{Digital Elevation Model (DEM)}

Digital Elevation Model (DEM) is a 3D

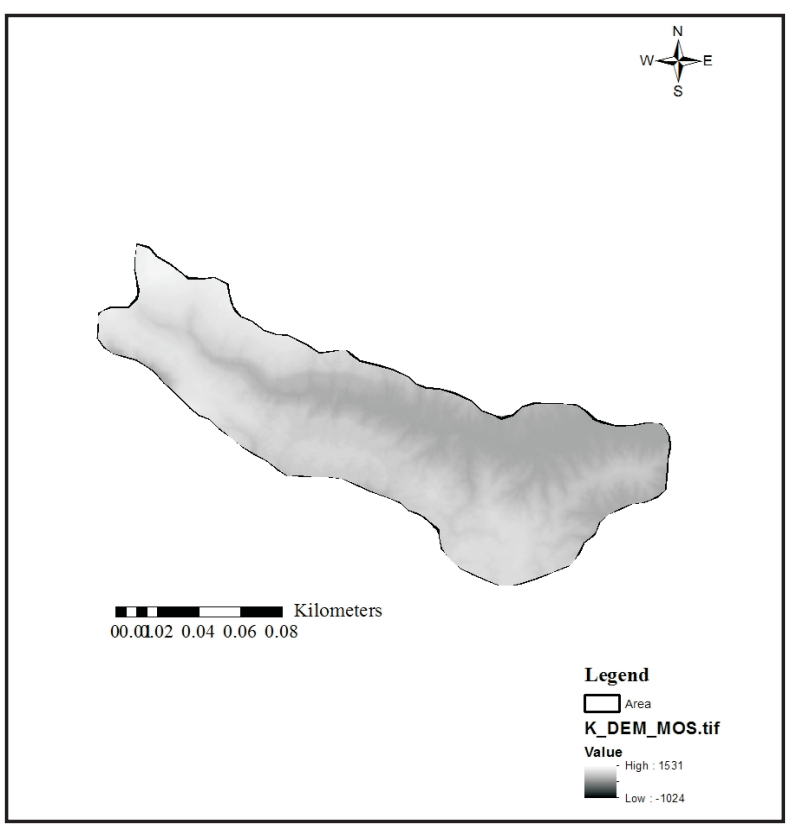

Fig. 1. Digital evevation model of Kansa watershed 
representation of terrain's surface (Fig. 1). It is used for extracting parameters for geomorphology, modelling water flow for hydrology mass movement, creation of relief maps and base mapping. DEM images $(30 \mathrm{~m}$ resolution) were downloaded from Bhuvan website (http://bhuvan-noeda.nrsc.gov.in).

\section{Watershed delineation}

Watershed delineation plays an important role in its management. Arc-GIS 9.3 was used for the purpose of catchment delineation using Survey of India toposheets (47 G/16, 1:50,000 scale). Toposheets provide information related to the location, drainage network and contours.

Table 1. Formulae used for characterization of different morphometric parameters of watershed
Morphological characterization is a systematic description of watershed geometry. The geometry of drainage basin and its stream channel system requires measurements on linear aspect of drainage network, areal aspect of drainage basin and relief aspect of channel network and contributing ground slopes. (Table 1)

\section{Results and Discussion \\ Morphological characteristics}

The Kansa watershed is fern shaped welldeveloped drainage network up to fourth stream order.

$\begin{array}{ccccc}\begin{array}{c}\text { Morphometric } \\ \text { Parameters }\end{array} & \text { Symbol } & \text { Formula } & \text { Particulars } & \text { Reference }\end{array}$

Linear aspect of drainage network

\begin{tabular}{|c|c|c|c|c|}
\hline Stream order & $\mathrm{u}$ & $\begin{array}{l}\text { Hierarchical } \\
\text { Rank }\end{array}$ & $\mathrm{u}$-stream order & Strahler (1964) \\
\hline Stream number & $\mathrm{N}_{\mathrm{u}}$ & . & $\begin{array}{l}\mathrm{N}_{\mathrm{u}}-\text { Number of stream of } \\
\text { order } \mathrm{u}\end{array}$ & Strahler(1964) \\
\hline Bifurcation ratio & $\mathrm{R}_{\mathrm{b}}$ & $\mathrm{R}_{\mathrm{b}}=\frac{\mathrm{N}_{\mathrm{u}}}{\mathrm{N}_{\mathrm{u}+1}}$ & $\begin{array}{l}\mathrm{R}_{\mathrm{b}}-\text { bifurcation ratio } \\
\mathrm{N}_{\mathrm{u}} \text {-number of streams of } \\
\text { order } \mathrm{u} \\
\mathrm{N}_{\mathrm{u}+1}-\text { number of streams of } \\
\text { order } \mathrm{u}+1\end{array}$ & Schumn(1956) \\
\hline Mean stream length & $\overline{\mathrm{L}}_{\mathrm{u}}$ & $\overline{\mathrm{L}}_{\mathrm{u}}=\frac{\sum_{\mathrm{i}=1} \mathrm{~L}_{\mathrm{u}}}{\mathrm{N}_{\mathrm{u}}}$ & $\begin{array}{l}\bar{L}_{u} \text { - mean length of channel } \\
\text { of order } u \\
\mathrm{~L}_{u} \text { - total length of stream } \\
\text { segments of order } u\end{array}$ & Hortan (1945) \\
\hline Stream length ratio & $\mathrm{R}_{\mathrm{L}}$ & $\mathrm{R}_{\mathrm{L}}=\frac{\overline{\mathrm{L}}_{\mathrm{u}}}{\overline{\mathrm{L}}_{\mathrm{u}-1}}$ & $\begin{array}{l}\bar{L}_{u-1} \text { - mean length of } \\
\text { stream of next lower order }\end{array}$ & Hortan(1945) \\
\hline
\end{tabular}




\begin{tabular}{|c|c|c|c|c|}
\hline \multicolumn{5}{|c|}{ Areal Aspects of Drainage Networks } \\
\hline Form factor & $\mathrm{R}_{\mathrm{f}}$ & $\mathrm{R}_{\mathrm{f}}=\frac{\mathrm{A}_{\mathrm{u}}}{\mathrm{L}_{\mathrm{b}}^{2}}$ & $\begin{array}{l}\mathrm{A}_{\mathrm{u}}-\text { basin area } \\
\mathrm{L}_{\mathrm{b}} \text { - basin length }\end{array}$ & Hortan (1945) \\
\hline Circulatory ratio & $\mathrm{R}_{\mathrm{c}}$ & $\mathrm{R}_{\mathrm{C}}=\frac{\mathrm{A}_{\mathrm{U}}}{\mathrm{A}_{\mathrm{C}}}$ & $A_{C}$ - area of circle & Miller(1953) \\
\hline Elongation ratio & $\mathrm{R}_{1}$ & $\mathrm{R}_{1}=\frac{\mathrm{D}_{\mathrm{C}}}{\mathrm{L}_{\mathrm{bm}}}$ & $\begin{array}{l}\mathrm{D}_{\mathrm{c}} \text { - diameter of circle } \\
\mathrm{L}_{\mathrm{bm}} \text {-maximum basin length }\end{array}$ & Schumn (1956) \\
\hline Drainage density & $\mathrm{D}_{\mathrm{d}}$ & $\mathrm{D}_{\mathrm{d}}=\frac{\mathrm{L}}{\mathrm{A}}$ & $\begin{array}{l}\mathrm{L} \text { - Total length of all stream } \\
\text { segments } \\
\text { A - watershed area }\end{array}$ & Hortan (1945) \\
\hline $\begin{array}{l}\text { Constant of } \\
\text { channel } \\
\text { maintenance }\end{array}$ & $\mathrm{C}$ & $\mathrm{C}=\frac{1}{\mathrm{D}_{\mathrm{d}}}$ & $D_{d}$ - drainage density & Hortan(1945) \\
\hline Drainage texture & $\mathrm{T}$ & $\mathrm{T}=\frac{\mathrm{N}}{P}$ & $\begin{array}{l}\mathrm{N} \text { - Total number of streams } \\
\text { of all order } \\
\mathrm{P} \text { - Basin perimeter }\end{array}$ & $\operatorname{Hortan}(1945)$ \\
\hline \multicolumn{5}{|c|}{ Relief Aspects of Drainage Networks } \\
\hline Relief & $\mathrm{H}$ & & H- relief & Schumn (1956) \\
\hline Relief ratio & $\mathrm{R}_{\mathrm{n}}$ & $\mathrm{R}_{\mathrm{n}}=\frac{\mathrm{H}}{\mathrm{L}_{\mathrm{h}}}$ & $\mathrm{L}_{\mathrm{h}}$ - horizontal distance & Schumn(1956) \\
\hline Relative relief & $\mathrm{R}_{\mathrm{hp}}$ & $\mathrm{R}_{\mathrm{hp}}=\frac{\mathrm{H}}{\mathrm{P}} \times 100$ & $\begin{array}{l}\mathrm{H} \text { - basin relief } \\
\mathrm{P}-\text { perimeter of basin }\end{array}$ & Schumn (1956) \\
\hline $\begin{array}{l}\text { Ruggedness } \\
\text { number }\end{array}$ & HD & $\mathrm{HD}=\mathrm{H} \times \mathrm{D}_{\mathrm{d}}$ & $\begin{array}{l}\mathrm{H} \text { - basin relief } \\
\mathrm{D}_{d} \text { - drainage density }\end{array}$ & Schumn(1956) \\
\hline $\begin{array}{l}\text { Length of oerland } \\
\text { flow }\end{array}$ & $\mathrm{L}_{\mathrm{g}}$ & $\mathrm{L}_{\mathrm{g}}=\frac{1}{2 \mathrm{D}_{\mathrm{d}}}$ & $\mathrm{D}_{\mathrm{d}}$ - drainage density & Schumn (1956) \\
\hline
\end{tabular}

The ranking of the streams has been carried out based on the method proposed by Strahler (1964). It is observed that the maximum frequency is in case of first order streams. It is also noticed that there is a decrease in stream frequency as the stream order increases (Table 2). The watersheds with high values of first order streams is susceptible to sudden flash floods after heavy rainfall in the down streams.

Table 2. Linear aspects of the drainage network

\begin{tabular}{|c|c|c|c|c|c|}
\hline $\begin{array}{l}\text { River } \\
\text { basin }\end{array}$ & $\begin{array}{c}\text { Stream } \\
\text { order (u) }\end{array}$ & $\begin{array}{c}\text { Number of } \\
\text { streams }(\mathrm{Nu})\end{array}$ & $\begin{array}{c}\text { Total length of } \\
\text { streams in } \mathrm{km}(\mathrm{Lu})\end{array}$ & $\begin{array}{r}\text { Mean stream } \\
\text { length } \mathbf{k m}\left(\mathbf{L}_{\mathrm{sm}}\right)\end{array}$ & $\begin{array}{c}\text { Stream length } \\
\text { Ratio }\left(L_{m}\right)\end{array}$ \\
\hline \multirow{4}{*}{ Kansa } & 1 & 129 & 102.46 & 0.79 & - \\
\hline & 2 & 32 & 31.32 & 0.98 & 0.31 \\
\hline & 3 & 2 & 15.15 & 7.58 & 0.48 \\
\hline & 4 & 1 & 21.29 & 21.29 & 1.40 \\
\hline \multicolumn{5}{|c|}{ Bifurcation ratio $(\mathrm{R})$} & $\begin{array}{c}\text { Mean } \\
\text { Bifurcation } \\
\text { Ratio } \\
\end{array}$ \\
\hline \multirow{2}{*}{\multicolumn{2}{|c|}{$\begin{array}{l}1^{\text {st }} \text { order/ } \\
2^{\text {nd }} \text { order }\end{array}$}} & \multicolumn{2}{|c|}{$2^{\text {nd }}$ order/ } & $3^{\mathrm{rd}}$ order/ & \multirow{3}{*}{7.34} \\
\hline & & \multicolumn{2}{|c|}{$3^{\text {rd }}$ order } & $4^{\text {th }}$ order & \\
\hline \multicolumn{2}{|r|}{4.03} & \multicolumn{2}{|c|}{16} & 2 & \\
\hline
\end{tabular}




\section{Stream number}

The numbers of the stream segments decreased with increase in the stream order. The higher stream order indicated lesser permeability and infiltration. It is observed that maximum frequency is in the case of first order streams. It is also noticed that there is a decrease in stream frequency with an increase in the stream order.

\section{Stream length}

The number of streams of various orders in a subwatershed was counted and their lengths from mouth to drainage divide were measured. For this watershed, the total length of stream segments is maximum in first order streams and decreases as the stream order increases. This indicates that the basin is subjected to erosion and also that some areas of the basin are characterized by variation in lithology and topography (Singh and Singh 1997; Vittala et al. 2004 and Chopra et al. 2005).

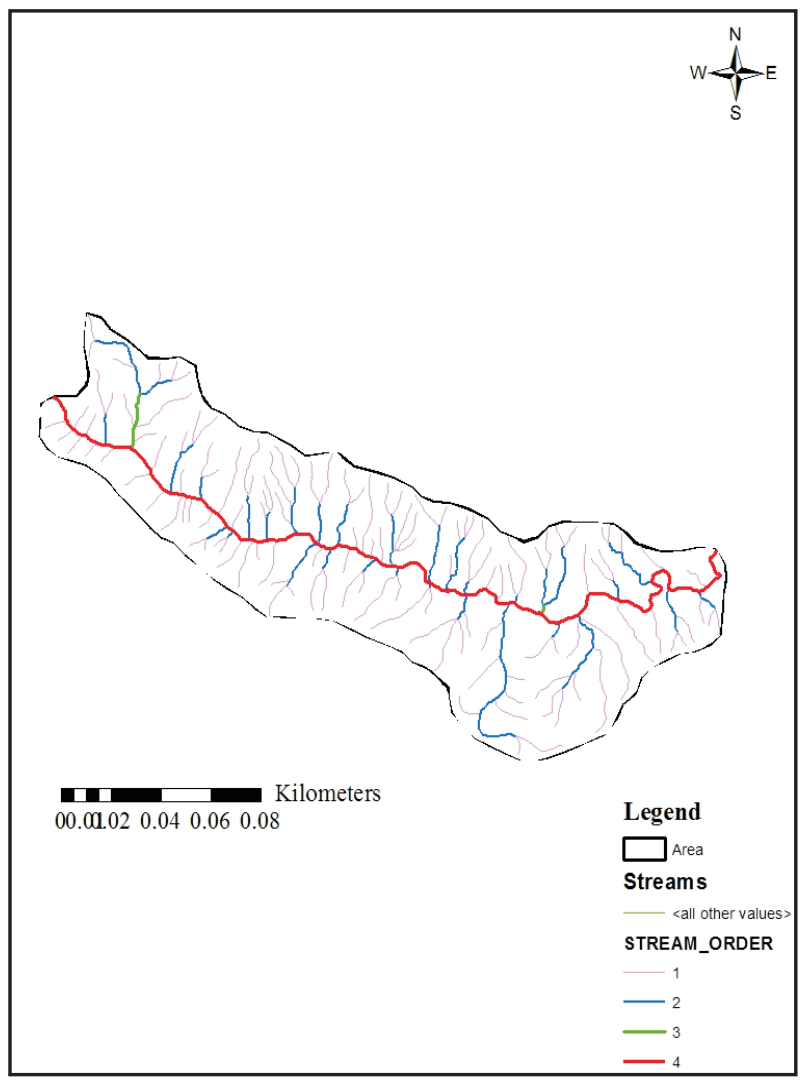

Fig. 2. Stream order map of Kansa watershed

\section{Bifurcation ratio}

The mean bifurcation ratio is 7.34 (Table 2 ). The $\mathrm{R}_{\mathrm{b}}$ values of the area indicate that there is a uniform increase in $\mathrm{R}_{\mathrm{b}}$ values from the first order streams to the third order streams. There was decrease in the $\mathrm{R}_{\mathrm{b}}$ values from the third to fourth order streams. These differences depend the geological and lithological development of the drainage basin (Strahler 1964). Bifurcation ratios range between 3.0 and 5.0 for basins in which the geologic structures do not distort the drainage pattern (Strahler 1964). Strahler (1952) demonstrated that bifurcation ratio shows a small range of variation for different regions or for different environment.

\section{Mean stream length}

Total length of stream decreases with increase in the order of stream. This may be due to the geomorphologic, lithological and structural control and contrast.

\section{Stream length ratio}

The variations in stream length ratio in the area were due to variations in slope and topography.

\section{Areal aspects of drainage networks}

The data pertaining to areal aspect of drainage network in Kansa watershed are presented in table 3.

\section{Form factor}

The form factor value (Table 3) of the watershed was 0.21 . The lower value of the form factor represent elongated shape of watershed. The elongated basin with low form factor indicated that the basin had flatter peak for longer duration. The flood flows in such elongated basins are easier to manage than that of the circular basin. 
Table 3. Areal aspects of the drainage network

\begin{tabular}{clcc}
\hline Sr. No. & Morphometric Parameter & Symbol & Values \\
\hline 1 & Area $(\mathrm{sq} . \mathrm{km})$ & $\mathrm{A}$ & 62.50 \\
2 & Perimeter $(\mathrm{km})$ & $\mathrm{P}$ & 43.24 \\
3 & Basin length $(\mathrm{km})$ & $\mathrm{L}_{\mathrm{b}}$ & 17.08 \\
4 & Form factor & $\mathrm{R}_{\mathrm{F}}$ & 0.21 \\
5 & Circularity ratio & $\mathrm{R}_{\mathrm{C}}$ & 0.42 \\
6 & Elongation ratio & $\mathrm{R}_{\mathrm{L}}$ & 0.52 \\
7 & Drainage density $\left(\mathrm{km} \mathrm{km}^{-2}\right)$ & $\mathrm{D}_{\mathrm{d}}$ & 2.50 \\
8 & Drainage texture $\left(\mathrm{km} \mathrm{km}^{-2}\right)$ & $\mathrm{T}$ & 3.79 \\
9 & Constant of channel maintenance $\left(\mathrm{km}^{2} \mathrm{~km}^{-1}\right)$ & $\mathrm{C}$ & 0.40 \\
\hline
\end{tabular}

\section{Circulatory ratio}

The circulatory ratio of the watershed was 0.42 , indicating that it is elongated in shape (Miller 1953). The basin is characterised by high to moderate relief and the drainage system was structurally controlled. It also indicates that the basin has a low discharge of runoff.

\section{Elongation ratio}

The elongation ratio of the watershed was 0.52 . This indicates that the catchment is of elongated shape (Strahler 1964).

\section{Drainage density}

The drainage density of the watershed was 2.50 $\mathrm{km} / \mathrm{km}^{2}$. The high drainage density is due to the regions of weak or impermeable surface materials, sparse vegetation, and mountainous relief. Also, high drainage density leads to fine drainage texture (Strahler 1964).

\section{Constant of channel maintenance}

The constant of channel maintenance is 0.40 $\mathrm{km}^{2} \mathrm{~km}^{-1}$ indicating that the magnitude of surface area of watershed needs sustain unit length of stream segment. Drainage texture

The drainage density and drainage frequency have been collectively defined as drainage texture. The drainage texture of the watershed is 3.79 $\mathrm{km}^{-1}$. Drainage texture shows the relative spacing of the drainage line. As the drainage texture is less than 8 , it shows fine drainage texture.

\section{Relief aspects of drainage network}

Relief

Total relief for the watershed is $0.56 \mathrm{~km}$ (Table 4). This indicates moderate relief and steep slope in the watershed.

\section{Reliefratio}

The relief ratio is 0.03 which indicates the presence of hilly region in the watershed.

\section{Relative relief}

Relative relief for the watershed is 0.01 which is low.

\section{Ruggedness number}

This number represents that if drainage density increased keeping relief as constant, the average horizontal distance from drainage divide to the adjacent channel is reduced. On the other hand if relief is increased by keeping drainage density constant, the elevation difference between the drainage divide and adjacent channel goes on increasing. The ruggedness number was 1.39 .

\section{Length of overland flow}

The length of overland flow of the area is 0.20 $\mathrm{km}^{2} \mathrm{~km}^{-1}$. The high value of length of the overland flow indicates high surface run-off, whereas low value indicate low surface run-off. In the study area, the low value indicates the low surface run-off. 
Table 4. Relief aspects of the drainage network

\begin{tabular}{cll}
\hline \multicolumn{1}{c}{ SI. No. } & \multicolumn{1}{c}{ Parameter } & Values \\
\hline 1. & Slope $(\%)$ & $0-25$ \\
2. & Relief $(\mathrm{km})$ & 0.56 \\
3. & Relief ratio & 0.03 \\
4. & Relative relief & 0.01 \\
5. & Ruggedness number & 1.39 \\
6. & Length of overland flow $\left(\mathrm{km}^{2} \mathrm{~km}^{-1}\right)$ & 0.20 \\
\hline
\end{tabular}

\section{Conclusion}

The Stream frequency decreased with the increase in the stream order in the watershed. The mean bifurcation ratio is high (7.34) suggesting that the basin is largely controlled by structure. There are variations in stream length ratio in the watershed due to variations in slope and topography. The elongation ratio of watershed is 0.52 which indicates flatter peak flow for longer duration. The watershed characteristics will be useful in hydrological modeling of the watershed.

\section{References}

Bante, R.R., Srivastava, R., Nagaraju, M.S.S. and Jagdish Prasad (2012). Characterization and evaluation of land resources for management of Taroda watershed of Nagpur district, Maharashtra using Resourcesat-1 and GIS. Journal of the Indian Society of Soil Science 59, 266-273.

Barber, M.D. (2005). Hydrogeomorphology, Fundamental Applications and Techniques. (New India Publishing Agency, New Delhi).

Chopra, R., Sharma, P.K. and Diman, R.D. (2005). Morphometric Analysis of Sub-watershed in Gurdespur District, Punjab using RS and GIS. Indian Society of Remote Sensing 33, 531-539.

Debashis, C. and Chandrashekharan, H. (2002). Morphometric Analysis of a Watershed using Remote Sensing and GIS. Division of
Agricultural Physics and Water Technology Centre, Indian Agricultural Research Institute, New Delhi 2, 52-56.

Horton, R.E. (1945). Erosional Development of streams and their drainage basins; hydrophysical approach to quantitative morphology. Geological Society of America 56, 275-370.

Kuldeep, P. and Upasana, P. (2011). Quantitative morphometric analysis of a watershed of Yamuna basin, India using ASTER (DEM) Data and GIS. International Journal of Geomatics and Geosciences 2, 248-269.

Miller, V.C. (1953). A quantitative geomorphic study of drainage basin characteristics on the Clinch Mountain area, Virgina and Tennessee. pp. 389402. (Columbia University, Department of Geology, ONR, New York).

Nageswara, R.K., Swarna, L.P., Arunkumar, P. and Hari, K.M. (2010). Morphometric analysis of Gostani river basin in Andhra Pradesh state, (India), using spatial information technology. International Journal of Geomatics and Geosciences 1, 179-187.

Pandey, A., Chowdary, V.M. and Mal, B.C. (2004). Morphological analysis and watershed management using GIS. Hydrology Journal 27, 71-84

Schumn, S.A. (1956). Evaluation of drainage systems and slopes in badlands at Perth Amboy, New Jersy. Geological Society of American Bulletien No. 67, 597-646. 
Singh, S. and Singh, M.C. (1997). Morphometric analysis of Kanhar river basin. National Geographical Journal of India 43, 31-43.

Sharma, S.A. (2014). Morphometrical analysis of Imphal river basin using GIS. International Journal of Geology, Earth and Environmental Sciences 4, 138-144.

Soni, S., Tripathi, S. and Maurya, A.K. (2013). GIS based morphometric characterization of miniwatershed - Rachhar Nala of Anuppur district, Madhya Pradesh. International Journal of Advanced Technology and Engineering Research 3, 32-38.
Strahler, A.N. (1952). Hypsometric (area-attitude) analysis of erosional topography. Geological Society of America 63, 1117-1142.

Strahler, A. N. (1964). Quantitative geomorphology of drainage basin and channel networks. In 'Handbook of Applied Hydrology'. (Eds. V. Chow ) pp. 439-476. (McGraw Hill, New York).

Vittala, S., Srinavasa, G.S. and Honnegowda. (2004). Morphometric analysis of sub-watersheds in the Pavagada area Tumkur district, South India using Remote Sensing and GIS Techniques. Journal of Indian Society of Remote Sensing 32, 235-251.

Received: October, 2018

Accepted: April, 2019 